\title{
Beata Zaleska
}

Politechnika Koszalińska

e-mail: beata.zaleska@tu.koszalin.pl

\section{AUDYT WEWNĘTRZNY W SZPITALACH DZIAŁAJĄCYCH W FORMIE SAMODZIELNYCH PUBLICZNYCH ZAKŁADÓW OPIEKI ZDROWOTNEJ (WYBRANE ZAGADNIENIA) \\ INTERNAL AUDIT IN HOSPITALS FUNCTIONING IN THE FORM OF AUTONOMOUS PUBLIC HEALTH CENTRES (SELECTED ISSUES)}

DOI: $10.15611 / \mathrm{pn} .2018 .521 .23$

JEL Classification: M42

Streszczenie: Celem opracowania jest wskazanie podstaw prawnych funkcjonowania audytu wewnętrznego w szpitalach, które działają w formie samodzielnych publicznych zakładów opieki zdrowotnej, a także ustalenie, czy były realizowane badania dotyczące efektywności audytu wewnętrznego w tych podmiotach leczniczych. Metody badawcze zastosowane w pracy to analiza literatury przedmiotu, aktów prawnych, informacji zawartych na stronach internetowych Ministerstwa Finansów i Ministerstwa Zdrowia. Można postawić tezę, że audyt wewnętrzny jest jednym z czynników wpływających na jakość zarządzania samodzielnym publicznym zakładem opieki zdrowotnej. Analiza literatury przedmiotu pokazała istniejącą lukę w zakresie badań nad funkcjonowaniem audytu wewnętrznego w szpitalach i jego efektywnością. Istnieje potrzeba prowadzenia takich badań, a inspiracją do nich mogą być raporty umieszczane na stronie internetowej Ministerstwa Finansów, obejmujące wskaźniki opisujące komórki audytu wewnętrznego i wyniki ich pracy.

Słowa kluczowe: szpital, audyt wewnętrzny, efektywność, wskaźniki, zarządzanie.

Summary: The aim of this work is to indicate legal bases of functioning of an internal audit at hospitals that function in the form of an autonomous public health centre, as well as to determine whether studies on efficiency of internal audit at hospitals were realised. Research methods used in the work include an analysis of literature, legal acts, information published at websites of the Ministry of Finance and the Ministry of Health. It is also possible to propose a thesis that an internal audit is one of factors having an influence on the quality of management over an autonomous public health centre. The analysis of literature revealed an existing gap in the scope of studies on the functioning of an internal audit at hospitals. There exists a necessity to conduct such studies, which can be inspired by reports published at the website of the Ministry of Finance, covering indicators describing units of an internal audit, as well as results of their work.

Keywords: hospital, internal audit, efficiency, indicators, management. 


\section{Wstęp}

Zgodnie z ustawą o finansach publicznych [Ustawa z 27 sierpnia 2009] do jednostek objętych obowiązkiem prowadzenia audytu wewnętrznego należą między innymi te, które działają w sektorze opieki zdrowotnej. Dotyczy to Ministerstwa Zdrowia, Narodowego Funduszu Zdrowia, a także samodzielnych publicznych zakładów opieki zdrowotnej. Zgodnie z rozporządzeniem z 2006 roku w sprawie kwot, których przekroczenie powoduje obowiązek prowadzenia audy tu wewnętrznego $\mathrm{w}$ jednostkach sektora finansów publicznych [Rozporządzenie z 24 czerwca 2006], Minister Finansów wskazał kwotę 40 mln zł przychodów i wydatków jako tę, której przekroczenie powoduje obowiązek prowadzenia audytu wewnętrznego w samodzielnych publicznych zakładach opieki zdrowotnej. Kierownicy samodzielnych publicznych zakładów opieki zdrowotnej, których organem założycielskim nie jest jednostka samorządu terytorialnego, składają pisemną informację do Ministra Finansów o rozpoczęciu prowadzenia audytu wewnętrznego. Na wniosek Ministra Finansów przedstawiają też informacje i dokumenty związane z prowadzeniem audytu wewnętrznego. Warto wspomnieć, że przepisy ustawy o finansach publicznych przewidują sytuację, w której kierownicy jednostek decydują się na prowadzenie audytu wewnętrznego dobrowolnie. Audyt wewnętrzny w samodzielnym publicznym zakładzie opieki zdrowotnej może prowadzić audytor zatrudniony na podstawie umowy o pracę, który jest pracownikiem zakładu, lub audytor, który wykonuje usługi z zakresu audytu wewnętrznego. Audytor usługodawca może być zatrudniony w szpitalu, w którym wartość przychodów i wydatków nie przekroczyła kwoty 100000 tys. zł lub jest zatrudnionych mniej niż 200 pracowników. Warto dodać, że niezależnie od formy zatrudnienia audytor wewnętrzny wykonuje zadania zgodnie $\mathrm{z}$ obowiązującymi w zakresie audytu wewnętrznego przepisami ustaw, rozporządzeń, a także komunikatów, wytycznych wydawanych przez Ministra Finansów i zgodnie z przyjętymi do stosowania w Polsce standardami audytu wewnętrznego [Komunikat z 19 lutego 2009].

Zgodnie z ustawą o finansach publicznych z roku $2009 \mathrm{w}$ ministerstwach, w tym w Ministerstwie Zdrowia, zostały powołane komitety audytu. W art. 288 ustawy wskazano, że celem komitetu audytu jest doradztwo na rzecz Ministra Zdrowia $\mathrm{w}$ zakresie kontroli zarządczej i audytu wewnętrznego, tak aby były one adekwatne, skuteczne i efektywne. Do zadań komitetu audytu w myśl art. 289 ustawy o finansach publicznych należą między innymi: ustalanie priorytetów do planów audytu, przeglądanie istotnych wyników audytu i monitorowanie ich wdrożenia, przegląd sprawozdań z wykonania planu audytu, monitorowanie efektywności pracy audytu wewnętrznego, wyrażenie zgody na rozwiązanie stosunku pracy oraz zmiany warunków płacy i pracy kierowników komórek audytu wewnętrznego. Wynika $\mathrm{z}$ tego, że audytorzy wewnętrzni zatrudnieni w samodzielnych publicznych zakładach opieki zdrowotnej, których organem założycielskim jest Skarb Państwa i uczelnie wyższe, mają lepszą ochronę stosunku pracy niż audytorzy zatrudnie- 
ni w samodzielnych publicznych zakładach opieki zdrowotnej, których organem założycielskim jest jednostka samorządu terytorialnego. Jednostki samorządu terytorialnego nie podlegają bowiem pod komitety audytu. Zatrudnienie audytora w jednostkach nadzorowanych przez jednostki samorządu terytorialnego jest uzależnione tylko od decyzji kierownika jednostki, a nie komitetu audytu. Warto dodać, że w rozporządzeniu z roku 2009 w sprawie komitetu audytu uregulowano kwestie związane z wymaganiami wobec członków niezależnego komitetu i ich wynagrodzeniami. Wskazano też, co powinien zawierać regulamin komitetu audytu [Rozporządzenie z 29 grudnia 2009].

Celem prowadzenia audytu wewnętrznego w samodzielnych publicznych zakładach opieki zdrowotnej zgodnie z art. 272 ustawy o finansach publicznych jest wspieranie kierownika jednostki w realizacji celów i zadań przez systematyczną ocenę kontroli zarządczej i czynności doradcze. Efektywność audytu wewnętrznego można więc ocenić między innymi na podstawie liczby zrealizowanych z powodzeniem celów i zadań.

\section{Istota i zadania audytu wewnętrznego w szpitalu prowadzonym w formie samodzielnego publicznego zakładu opieki zdrowotnej}

Szpital to podmiot leczniczy, który wykonuje świadczenia zdrowotne całą dobę. Świadczenia polegają na diagnozowaniu, leczeniu, pielęgnacji i rehabilitacji pacjentów [Ustawa z 15 kwietnia 2011]. Szpitale akademickie, których organem założycielskim jest uczelnia wyższa, realizują oprócz działalności leczniczej również działalność badawczą i dydaktyczną. Obecnie większość szpitali w Polsce działa w ramach systemu podstawowego szpitalnego zabezpieczenia świadczeń opieki zdrowotnej (zwanego dalej system PSZ). Obowiązuje on od roku 2017. Wyróżniono w nim szpitale poziomu I powiatowe, poziomu II wojewódzkie, poziomu III wieloprofilowe szpitale specjalistyczne. Do systemu PSZ należą też szpitale onkologiczne i pulmonologiczne, pediatryczne i ogólnopolskie (utworzone przez instytuty i uczelnie medyczne) [Rozporządzenie z 13 czerwca 2017]. Szpitale, które są w systemie PSZ, mają różne formy organizacyjno-prawne, między innymi działają $\mathrm{w}$ formie samodzielnych publicznych zakładów opieki zdrowotnej. Szpitale pozyskują w większości środki finansowe na zasadzie ryczałtu w formie budżetu wypłacanego z góry przed realizowaniem świadczeń zdrowotnych. W tym celu podpisywana jest umowa $z$ Narodowym Funduszem Zdrowia, a pieniądze wypłacane w formie ryczałtu pochodzą ze składek publicznych. Możliwe jest też finansowanie niektórych świadczeń zdrowotnych na dotychczasowych zasadach systemu Jednorodnych Grup Pacjentów. W tym systemie środki finansowe wypłacane są na podstawie kontraktu zawartego z Narodowym Funduszem Zdrowia po wykonaniu świadczeń zdrowotnych w okresie sprawozdawczym, na który była zawarta umowa [Ustawa $\mathrm{z}$ 27 sierpnia 2004]. 
Szpitale dysponują środkami publicznym, których wartość w systemie opieki zdrowotnej jest uwarunkowana przychodami z tytułu wynagrodzeń i stopami procentowymi ustalonymi dla składki zdrowotnej. Są to środki ograniczone. Dlatego tak ważne jest podnoszenie efektywności działania szpitala, który dysponuje ograniczonymi środkami finansowymi, a wykonuje złożoną działalność i ma rozbudowaną strukturę organizacyjną. Efektywność w szpitalu można rozumieć jako realizację celów społecznych (zdrowotnych) i ekonomicznych. Efektywność ekonomiczna może oznaczać realizację określonych celów przy możliwie najniższych kosztach lub maksymalizację pożądanych efektów przy danym poziomie zasobów [Jakubowska 2017].

Efektywność działania może być uzyskana poprzez podejmowanie prawidłowych decyzji zarządczych przez kierowników szpitali. Decyzje w szpitalu dotyczą zarówno działalności medycznej, jak i ekonomicznej i związane są z oddziaływaniem na wiele procesów odbywających się w podmiocie leczniczym. Decyzje związane są bezpośrednio z wyznaczonymi do realizacji celami i zadaniami i muszą sprzyjać ich osiągnięciu. Nieprzemyślane, nietrafnie podjęte decyzje rodzą ryzyko niezrealizowania celów. Jednym z narzędzi zarządzania ułatwiających podejmowanie prawidłowych decyzji w szpitalu jest audyt wewnętrzny.

Audyt wewnętrzny można postrzegać jako nowoczesny instrument zarządzania, zorientowany na cele szpitala, identyfikujący i oceniający ryzyko działalności, wykorzystywany w sposób niezależny i obiektywny w celu tworzenia wartości dodanej i usprawniania działalności [Winiarska 2008].

Do zadań audytora wewnętrznego można zaliczyć badanie każdego obszaru działalności podmiotu leczniczego w zakresie [Winiarska 2005; Komunikat z 18 lipca 2006]:

- przestrzegania przepisów prawa, regulacji wewnętrznych jednostki, programów, strategii, standardów ustanowionych przez właściwe organy,

- efektywności i gospodarności wykorzystania posiadanych zasobów,

- ustanowionych mechanizmów kontroli wewnętrznej oraz wiarygodności i rzetelności informacji operacyjnych, zarządczych i finansowych,

- zabezpieczenia mienia jednostki,

- programów i projektów w celu ustalenia zgodności funkcjonowania jednostki z planowanymi wynikami i celami.

Obowiązki audytora wewnętrznego reguluje rozporządzenie z roku 2015 w sprawie audytu wewnętrznego oraz informacji o pracy i wynikach tego audytu.

W rozporządzeniu z roku 2015 uregulowane są zagadnienia dotyczące upoważnienia dla audytora wewnętrznego, na podstawie którego przeprowadza on zadania audytowe, dokumentacji zadań audytowych, sposobu sporządzania planu audytu, elementów, jakie powinien zawierać plan audytu, sprawozdania z prowadzenia audytu wewnętrznego, planowania i realizacji zadania audytowego oraz informacji o jego wynikach, audytu wewnętrznego zleconego i oceny prowadzenia audytu wewnętrznego. 
Na uwagę zasługują regulacje dotyczące analizy ryzyka, która jest nieodłącznym elementem pracy audytora wewnętrznego i jest wykonywana zarówno w momencie sporządzania planu audytu na rok następny, jak i w trakcie realizacji zadania audytowego. W rozporządzeniu nie ma podanej metodologii sporządzenia analizy ryzyka, ale w tym zakresie audytor wewnętrzny może się posiłkować literaturą przedmiotu czy opracowaniami Ministerstwa Finansów, w których są podane metody analizy ryzyka [Czerwiński 2004; Ministerstwo Finansów 2003].

\section{Przegląd literatury w zakresie funkcjonowania audytu wewnętrznego w szpitalach działających w formie samodzielnych publicznych zakładów opieki zdrowotnej}

Ze względu na rangę audytu wewnętrznego w zarządzaniu szpitalem ważne jest badanie jego efektywności. Badania nad funkcjonowaniem audytu wewnętrznego mogłyby pokazać, czy realizuje on wszystkie przypisane mu zadania i cele i w jakim stopniu wpływa na poprawę jakości zarządzania szpitalem. Na podstawie dokonanej analizy literatury i zawartości stron internetowych instytucji, które nadzorują działalność audytu wewnętrznego w jednostkach sektora finansów publicznych, można stwierdzić, że występuje luka w badaniach nad funkcjonowaniem audytu wewnętrznego w szpitalach działających w formie samodzielnych publicznych zakładów opieki zdrowotnej.

Autorzy publikacji naukowych o audycie wewnętrznym koncentrują się przede wszystkim na jego funkcjonowaniu w jednostkach samorządu terytorialnego. Niewiele jest publikacji o audycie wewnętrznym w szpitalu. W tych opracowaniach autorzy koncentrują się na ogólnych zagadnieniach dotyczących funkcjonowania audytu wewnętrznego $\mathrm{w}$ sektorze ochrony zdrowia albo bardzo szczegółowych związanych z realizowaniem zadań audytowych w podmiocie leczniczym. Zagadnienia ogólne dotyczą:

- zakresu, celów audytu, jego przeprowadzania w jednostkach ochrony zdrowia [Wrona 2006; Szczepankiewicz 2010a],

- podstaw formalnych prowadzenia audytu wewnętrznego, kwalifikacji audytora wewnętrznego, roli i rodzajów audytu w szpitalu i zasad jego funkcjonowania [Szczepankiewicz 2010b],

- audytu wewnętrznego jako narzędzia poprawy zarządzania w jednostkach ochrony zdrowia, organizacji i zadań komitetu audytu w Ministerstwie Zdrowia, dokumentacji audytu wewnętrznego [Szczepankiewicz 2010c],

- audytu wewnętrznego jako narzędzia wspomagającego zarządzanie szpitalem i ocenę jakości systemu zarządzania oraz jakości usług w zakładzie opieki zdrowotnej [Korendowicz 2010; Dąbrowska 2010],

- doskonalenia jakości funkcjonowania audytu wewnętrznego w sektorze ochrony zdrowia [Szczepankiewicz 2010d]. 
Bardziej szczegółowe publikacje z zakresu audytu wewnętrznego w szpitalach obejmują zagadnienia związane z:

- audytem rentowności usług medycznych [Jarzębińska 2010],

- odpadów medycznych jako przedmiotu audytu wewnętrznego w szpitalu [Pawełczyk 2012],

- roli audytora wewnętrznego w badaniu due diligence [Foremna-Pilarska 2015].

W szczegółowych opracowaniach dotyczących audytu wewnętrznego autorzy koncentrują się przede wszystkim na opisie realizacji konkretnych zadań audytowych zapewniających i doradczych. Wskazują sposób analizy ryzyka i dokumentowanie zadania audytowego.

Analiza zawartości strony internetowej Ministerstwa Finansów wskazała wiele materiałów, które ministerstwo opracowuje na temat audytu wewnętrznego. Między innymi od roku 2010 publikowane są wskaźniki opisujące komórki audytu wewnętrznego i usługodawców oraz wyniki ich pracy. Wskaźniki publikowane są w raportach „Benchmarking audytu wewnętrznego w jednostkach sektora finansów publicznych". Dane służące do obliczenia wskaźników są pozyskiwane przez Ministerstwo Finansów z informacji o realizacji zadań z zakresu audytu wewnętrznego składanych przez kierowników jednostek. Wynika to z obowiązku zawartego w art. 295 ustawy o finansach publicznych [Ustawa z 27 sierpnia 2009]. Wzór informacji został opublikowany w komunikacie Ministra Finansów [Komunikat z 1 września 2016].

Uzasadnieniem do powstania raportu było udostępnianie audytorom wewnętrznym danych (średnich wartości wskaźników w grupach porównawczych badanych jednostek i przeciętnej wartości wskaźników) w celu dokonania przez nich badań porównawczych. Wyniki porównania w zamierzeniu Ministerstwa Finansów mają przyczynić się do podnoszenia efektywności i poprawy jakości audytu wewnętrznego prowadzonego w jednostce, a tym samym doprowadzić do wzrostu rangi audytu wewnętrznego i wzmocnienia jego pozycji [Raport 2017, s. 4].

Badanie z roku 2016 zostało opracowane na podstawie danych zgromadzonych z 573 jednostek. Jednostki podzielono według różnych kryteriów, a wyniki badań zostały przedstawione dla każdej grupy porównawczej. Grupy porównawcze wyróżniono według:

- wielkości jednostki mierzonej liczbą zatrudnionych w jednostce ogółem,

- wielkości jednostki mierzonej poziomem wydatków lub kosztów w zależności od formy organizacyjno-prawnej,

- wielkości komórek audytu wewnętrznego,

- zbliżonych zadań lub organizacji, lub formy organizacyjno-prawnej,

- obszaru audytu mierzonego liczbą zatrudnionych w jednostkach.

W raporcie obliczono i przedstawiono w każdej grupie porównawczej wskaźniki, takie jak:

- wyniki audytu wewnętrznego (wskaźniki: liczba zakończonych zadań zapewniających, liczba wydanych zaleceń), 
- jakość audytu wewnętrznego (wskaźniki: samoocena, ocena zewnętrzna, samoocena i ocena zewnętrzna, czas przeznaczony na szkolenia i rozwój zawodowy), - wydajność (efektywność) audytu wewnętrznego (wskaźniki: pracochłonność zadań zapewniających, pracochłonność czynności sprawdzających, średni czas przeznaczony na czynności doradcze, stopień realizacji planu audytu, wydajny czas audytu, procent zaleceń uznanych za zasadne).

Do każdego wskaźnika zostały przedstawione wzory lub formuła liczenia. Jednostka, która chce porównać się z przedstawionymi w raporcie, powinna najpierw określić, w której jest grupie porównawczej, a następnie na podstawie własnych danych obliczyć wskaźniki. Raport nie zawiera danych z jednostek, w których audyt wewnętrzny jest prowadzony przez usługodawcę, te jednostki bowiem nie mają obowiązku wypełniania określonych punktów informacji o realizacji zadań z zakresu audytu wewnętrznego. Mimo nieujęcia jednostek, w których audyt wewnętrzny prowadzi usługodawca, nic nie stoi na przeszkodzie, aby obliczyły one wskaźniki na podstawie przedstawionych wzorów i porównały je z przedstawionymi w raporcie wynikami.

Należy podkreślić, że w raporcie przygotowanym przez Ministerstwo Finansów w grupie porównawczej według zadań lub formy organizacyjno-prawnej wyróżniono szpitale. W badaniu z roku 2016 stanowiły one 9\% wszystkich jednostek zakwalifikowanych do grupy porównawczej. W raporcie nie scharakteryzowano jednak szczegółowo szpitali, które wzięły udział w badaniu (poziom systemu PSZ, specjalizacja, liczba łóżek, liczba oddziałów, wielkość przychodów, liczba obsługiwanych pacjentów), trudno więc wyciągnąć wnioski dotyczące efektywności audytu wewnętrznego w szpitalach. Trudno też dokonać porównań szpitali z innymi jednostkami (np. sądy czy służby mundurowe). Dotyczy to na przykład liczby zadań realizowanych przez audytora wewnętrznego w szpitalu. Ze względu na specyfikę działalności podmiotu leczniczego, który realizuje zarówno działania medyczne, jak i pozamedyczne, i złożoność obszarów ocenianych przez audytora wewnętrznego liczba zrealizowanych zadań audytowych w ciągu roku może być znacznie mniejsza niż w innych jednostkach, które wykonują jeden rodzaj nieskomplikowanej działalności.

Mimo pewnych niedoskonałości opracowywanie raportów przez Ministerstwo Finansów należy uznać za pozytywne działanie, które może być wskazówką dla jednostek, w jaki sposób mierzyć efektywność i jakość realizowanego audytu wewnętrznego. Porównanie z innymi jednostkami o tych samych parametrach (forma organizacyjno-prawna, liczba zatrudnionych audytorów, specyfika działania, wielkość przychodów i wydatków) może pomóc w dążeniu do osiągnięcia lepszych wyników audytu wewnętrznego. 


\section{Zakończenie}

Na podstawie przeprowadzonej analizy literatury przedmiotu można stwierdzić, że brakuje pogłębionych badań dotyczących funkcjonowania audytu wewnętrznego w szpitalach działających w formie samodzielnych publicznych zakładów opieki zdrowotnej. Autorzy publikacji koncentrują się najczęściej na ogólnych zagadnieniach, takich jak podstawy prawne prowadzenia audytu wewnętrznego w organizacjach opieki zdrowotnej, kwalifikacje audytora wewnętrznego, zadania komitetu audytu utworzonego w Ministerstwie Zdrowia, sposób realizacji konkretnego zadania audytowego w określonym obszarze działalności podmiotu leczniczego. Według autora opracowania istnieje potrzeba badań w zakresie efektywności audytu wewnętrznego w szpitalu, ponieważ jest on istotnym narzędziem zarządzania. Podstawą do takiego twierdzenia jest rola audytora wewnętrznego w zapewnieniu kierownika jednostki, że wykonywana przez niego kontrola zarządcza jest efektywna, adekwatna i skuteczna. Wzorem do opracowania metodologii badania efektywności audytu wewnętrznego w szpitalu mogą być wskaźniki oceny audytu wewnętrznego prezentowane w raportach Ministerstwa Finansów „Benchmarking audytu wewnętrznego w jednostkach sektora finansów publicznych".

\section{Literatura}

Czerwiński K., 2004, Audyt wewnętrzny, InfoAudit Sp. z o.o, Warszawa.

Dąbrowska E., 2010, Audyt wewnętrzny systemu zarzązania jakościa w zakładzie opieki zdrowotnej procesem oceny jakości system oraz jakości ustug, Pielęgniarstwo Polskie, nr 1(35), s. 25-27.

Foremna-Pilarska M., 2015, Rola audytora $w$ badaniu due diligence $w$ Regionalnym Centrum Medycznym Sp. z o.o. w Białogardzie, [w:] Efekty funkcjonowania audytu wewnętrznego i kontroli zarządczej, Zeszyty Naukowe Uniwersytetu Szczecińskiego, nr 864, Finanse, Rynki Finansowe, Ubezpieczenia, nr 76, t. 2, Szczecin, s. 51-59.

Jakubowska A., 2017, Efektywność w ochronie zdrowia - zarys problemu, [w:] Zarzadzanie organizacja w opiece zdrowotnej, wybrane aspekty, red. A. Jakubowska, M. Olkiewicz, Wydawnictwo Uczelniane Politechniki Koszalińskiej, Koszalin, s. 28-47.

Jarzębińska M., 2010, Audyt rentowności ustug medycznych, [w:] Audyt wewnętrzny w sektorze publicznym, red. J. Przybylska, CeDeWu, Warszawa, s. 133-151.

Korendowicz J., 2010, Audyt wewnętrzny jako narzędzie wspomagające zarządzanie szpitalem, [w:] Audyt wewnętrzny wedtug nowej ustawy o finansach publicznych, Zeszyty Naukowe Uniwersytetu Szczecińskiego, nr 621, Finanse, Rynki Finansowe, Ubezpieczenia, nr 30, s. 193-202.

Komunikat nr 16 Ministra Finansów z 18 lipca 2006 r. w sprawie ogłoszenia „Kodeksu etyki audytora wewnętrznego w jednostkach sektora finansów publicznych” i „Karty audytu wewnętrznego w jednostkach sektora finansów publicznych”, Dz. Urz. MF, nr 9, poz. 70.

Komunikat nr 1 Ministra Finansów z 19 lutego 2009 r. w sprawie standardów audytu wewnętrznego w jednostkach sektora finansów publicznych, Dz. Urz. MF, nr 2, poz. 12.

Komunikat nr 4 Ministra Finansów z 1 września 2016 r. w sprawie wzoru informacji o realizacji zadań z zakresu audytu wewnętrznego, Dz. Urz. Min. Fin., poz. 67. 
Pawełczyk M., 2012, Odpady medyczne jako przedmiot audytu wewnętrznego w szpitalu, [w:] Realizacja kontroli zarzadczej w sektorze finansów publicznych, Zeszyty Naukowe Uniwersytetu Szczecińskiego, nr 718, Finanse, Rynki Finansowe, Ubezpieczenia, nr 53, Szczecin, s. 379-390.

Podręcznik audytu wewnętrznego w administracji publicznej, Ministerstwo Finansów, marzec 2003, http://www.audyt.com/storage/pdf/metodyka/podrecznik_audytu_wewnetrznego_w_administracji_publicznej.pdf (22.05.2018).

Raport. Benchmarking audytu wewnętrznego w jednostkach sektora finansów publicznych, 2017, Ministerstwo Finansów, Departament Polityki Wydatkowej, Warszawa, https://www.mf.gov.pl/c/ document library/get file?uuid=36e1d105-0039-4c88-82c8-7e37d09053e $8 \&$ groupId=764034 (24.05.2018).

Rozporządzenie Ministra Finansów z 24 czerwca 2006 r. w sprawie kwot, których przekroczenie powoduje obowiązek prowadzenia audytu wewnętrznego w jednostkach sektora finansów publicznych, Dz.U. nr 112, poz. 763.

Rozporządzenie Ministra Finansów z 29 grudnia 2009 r. w sprawie komitetu audytu, Dz.U. nr 226, poz. 1826.

Rozporządzenie Ministra Finansów z 4 września 2015 r. w sprawie audytu wewnętrznego oraz informacji o pracy i wynikach tego audytu, Dz.U. z 22 lutego 2018, poz. 506.

Rozporządzenie Ministra Finansów z 13 czerwca 2017 r. w sprawie specjalizacji w ochronie zdrowia, Dz.U. z 24 czerwca 2017, poz. 1217.

Szczepankiewicz E.I., 2010a, The Role of Internal Audit in Hospitals, [w:] Cost, Organization and Management of Hospitals, eds. J. Stępniewski, M. Bugdol, Jagiellonian University Press, Kraków, s. $52-60$.

Szczepankiewicz E.I., 2010b, Charakterystyka audytu wewnętrznego w szpitalach, [w:] Innowacje organizacyjne w szpitalach, red. J. Stępniewski, P. Karnej, M. Kęsy, Wolters Kluwer, Warszawa.

Szczepankiewicz E.I., 2010c, Internal audit as a management improvement tool in the healthcare sector units, Polish Annals of Medicine, no. 17(1), s. 136-149.

Szczepankiewicz E.I., 2010d, Doskonalenie jakości funkcjonowania audytu wewnętrznego w sektorze ochrony zdrowia - wstęne studium analityczne zmian $w$ regulacjach formalnych $w$ latach 2002-2010, [w:] Współczesne wyzwania strukturalne i menedżerskie w ochronie zdrowia: problem zarządzania, red. R. Lewandowski, R. Walkowiak, Olsztyńska Wyższa Szkoła Informatyki i Zarządzania im. Prof. Tadeusza Kotarbińskiego, Olsztyn, s. 243-257.

Ustawa z 27 sierpnia 2004 r. o świadczeniach opieki zdrowotnej finansowanych z środków publicznych, Dz.U. nr 210, poz. 2135 ze zm.

Ustawa z 27 sierpnia 2009 r. o finansach publicznych, Dz.U. nr 157, poz. 1240.

Ustawa z 15 kwietnia 2011 r. o działalności leczniczej, Dz.U. z 7 października 2016 r., poz. 1638.

Winiarska K., 2005, Teoretyczne i praktyczne aspekty audytu wewnętrznego, Difin, Warszawa.

Winiarska K., 2008, Audyt wewnętrzny, Difin, Warszawa.

Wrona B., 2006, Audyt wewnętrzny w jednostkach ochrony zdrowia, Antidotum, nr 2, s. 20-27. 